\title{
Продуктивность бройлеров при включении в полнорационные комбикорма цельного зерна пшеницы
}

\author{
Хамитова В.3., кандидат сельскохозяйственных наук, начальник зоотехнического отдела \\ ООО «Челны-Бройлер» \\ Османян А.К., доктор сельскохозяйственных наук, профессор \\ Малородов В.В., ассистент \\ Российский государственный аграрный университет - МСХА имени К.А. Тимирязева
}

\begin{abstract}
Аннотация: Проведен эксперимент с иелью определения эфрективности быращивания бройлеров при использовании 6 составе комбикормов иельного зерна пшениць. Полученные 6 эксперименте результаты позболяют рекомендобать к полнорационном комбикормам для бройлеров добаблять иельное зерно пиеницы с 8- до 14-суточного бозраста 6 количестве 5\% от потребляемого птицей комбикорма, с 15 - до 21-суточного возраста - 15\%, с 22-до 28-суточного - 20\%, с 29- до 35-суточного - 30\% зерна. В последующий предубойный период, не позднее, чем за 4 суток до убоя, необходимо исключать цельное зерно из рациона. Данная схема повысила живую массу бройлеров 639 дней по сравнению с контролем, не получабиим иельное зерно, на 4,7\% (р<0,05), среднесуточный прирост живой массы - на 4,6\%, улучшила конверсию корма на 15,4\%, индекс эфрективности быращибания бройлеров - на 20,9\% и рентабельность производства мяса - на 14,2\%.
\end{abstract}

Ключебые слова: бройлеры, полнорационные комбикорма, цельное зерно пшениць, продуктивность, рентабельность.

Введение. В связи с ростом продуктивности бройлеров современных кроссов возникла необходимость совершенствования программ кормления птицы при одновременном соблюдении технологических нормативов выращивания $[6-8,10,11]$. В полнорационные комбикорма для бройлеров включают большое количество видов сырья, в котором большую долю занимает пшеница (до 70-75\%), как правило, в дробленом виде. С целью усовершенствования кормовых программ в кормлении бройлеров используют более дешевые компоненты, сохраняя нормированную питательность рационов. По оценке специалистов, введение цельного зерна пшеницы в состав комбикормов позволяет улучшить моторику мышечного желудка и функциональную активность тонкого отдела кишечника, в резуль- тате чего повышается конверсия корма, а стоимость корма снижается за счет уменьшения затрат на дробление зерна [2,5]. При скармливании цельного зерна увеличивается функциональная нагрузка на органы пищеварения, масса мускульного и железистого желудков увеличивается, усиливается секреция пищеварительных соков с повышенной кислотностью [3,4]. Необходима разработка программ кормления с учетом скармливания бройлерам цельного зерна пшеницы в возрастном и количественном аспектах, а также уточнение доли цельного зерна в структуре рационов и схем скармливания комбикормов, содержащих цельное зерно [1,9,12].

Целью опыта было определение эффективности производства мяса бройлеров при использовании в кормлении цельного зерна, а также разработка схем и доз его скармливания.
Эффективность выращивания бройлеров при включении в рационы цельного зерна пшеницы
Группа 1 (контрольная). Рацион без включения цельного зерна
Группа 2 (опытная).

Рацион с включением цельного зерна от 5 до $20 \%$
Группа 3 (опытная). Рацион с включением цельного зерна от 5 до $30 \%$
Рисунок 1. Схема исследований 


\begin{tabular}{|c|c|c|c|c|c|c|c|c|c|c|}
\hline \multirow{3}{*}{$\begin{array}{l}\text { Вoз- } \\
\text { раст, } \\
\text { сут. }\end{array}$} & \multirow{3}{*}{$\begin{array}{l}\text { Комби- } \\
\text { корм }\end{array}$} & \multicolumn{9}{|c|}{ Групnа } \\
\hline & & \multicolumn{3}{|c|}{1 контрольная } & \multicolumn{3}{|c|}{2 опытная } & \multicolumn{3}{|c|}{3 опытная } \\
\hline & & рацион & $\begin{array}{c}\text { ОЭ, } \\
\text { ккал/100 г }\end{array}$ & Сп, \% & рацион & $\begin{array}{c}\text { 0Э, } \\
\text { ккал/100 г }\end{array}$ & Сп, \% & рацион & $\begin{array}{c}\text { ОЭ, } \\
\text { ккал/100 г }\end{array}$ & Сп, \% \\
\hline $0-7$ & Престартер & OP & 305,4 & 22,645 & OP & 305,4 & 22,645 & OP & 305,4 & 22,645 \\
\hline $8-14$ & ПК-2 & OP & 300,2 & 22,319 & $\mathrm{OP}+5$ & 300,4 & 22,320 & $\mathrm{OP}+5$ & 300,4 & 22,320 \\
\hline $15-21$ & ПК-5-1 & OP & 309,5 & 21,544 & $\mathrm{OP}+15$ & 309,4 & 21,523 & $O P+15$ & 309,4 & 21,523 \\
\hline $22-28$ & ПК-5-2 & OP & 312,7 & 20,546 & $O P+20$ & 312,9 & 20,915 & $O P+20$ & 312,9 & 20,915 \\
\hline $29-35$ & ПК-6-1 & OP & 317,1 & 20,344 & $\mathrm{OP}+20$ & 315,2 & 20,657 & $\mathrm{OP}+30$ & 312,5 & 20,606 \\
\hline $36-39$ & ПК-6-2 & OP & 322,1 & 20,200 & OP & 322,1 & 20,200 & OP & 322,1 & 20,200 \\
\hline
\end{tabular}

\section{Материал и методика иссле-} дований. Схема эксперимента представлена на рис. 1 и в табл. 1. Методом случайной выборки были сформированы три группы суточных цыплят-бройлеров кросса «Кобб-500» (контрольная и две опытные) без разделения по полу, по 100 гол. в каждой. Бройлеров содержали в напольных секциях с плотностью посадки 20 гол./ м $^{2}$ до 39-суточного возраста, при фронте кормления 2,5 см/гол. и фронте поения 10 гол. на 1 ниппель.

До 7-суточного возраста птице всех групп скармливали основной рацион (ОР) престартерной фазы, содержащий 305,4 ккал/100 г обменной энергии (ОЭ) и 22,645\% сырого протеина (СП). С 8- до 14-суточного возраста в опытных группах 2 и 3 осуществляли кормление бройлеров полнорационным комбикормом стартовой фазы с добавлением 5\% цельного зерна пшеницы; с 15- до 21-суточного возраста добавляли к комбикорму стартовой фазы 15\% зерна; с 22- до 28-суточного к комбикорму ростовой фазы добавляли 20\% зерна. С 29- до 35-суточного возраста к комбикорму финишной фразы в группе 2 добавляли 20\% цельного зерна, в группе 3 - 30\% цельного зерна пшеницы. В предубойный период (36-39 суток) к комбикорму финишной фазы бройлерам всех групп зерно пшеницы не добавляли.

Результаты исследований и их обсуждение. Основные результаты выращивания бройлеров приведены в табл. 2. Живая масса бройлеров в 39 дней была достоверно выше в опытных груп- пах 2 и 3 по сравнению с контрольной группой соответственно на 93 и 108 г или на 4,0 и 4,7\% $(p<0,05)$. Скорость роста цыплят в группах 2 и 3 также была выше по сравнению с контрольной группой на 2,4 и 2,7 г/гол./сут. или на 4,1 и 4,6\% соответственно.

Показатели однородности и изменчивости живой массы в опытных группах незначительно снижалась по мере увеличения доли ввода цельного зерна при равной сохранности поголовья цыплят. При увеличении ввода цельного зерна в значительной мере снизился расход корма в опытных группах 2 и 3 на 1 кг прироста: соответственно на 0,15 и 0,25 кг (на $8,7$ и $15,4 \%)$ в сравнении с контрольной группой. Индекс эффективности выращивания бройлеров в группе 3 был выше по сравнению с группами 1 и 2 на 62 и 27 единиц соответственно (на 20,9 и 8,1\%).

По окончании эксперимента был выполнен расчет экономиче- ской эффективности использования новых схем кормления с использованием цельного зерна в расчете на 1000 голов суточных цыплят (табл. 3).

Было установлено, что выручка от реализации потрошеных тушек бройлеров в группах 2 и 3 выше, чем в группе 1, на 3,6 и 5,8 тыс. руб. соответственно. Суммарные затраты на производство мяса бройлеров в убойной массе в опытных группах оказались ниже на 5,0 и 9,3 тыс. руб., что привело к увеличению прибыли в группах 2 и 3 на 8,6 и 15,1 тыс. руб. по сравнению с контрольной группой. Уровень рентабельности производства мяса в группах 2 и 3 был выше по сравнению с контрольной группой на 7,8 и 14,2\% соответственно.

Заключение. Результаты эксперимента позволяют констатировать зоотехническую и экономическую целесообразность использования схемы кормления бройлеров с включением в комбикорма цельного зерна пшеницы в период

Таблица 2. Зоотехнические показатели выращивания бройлеров

\begin{tabular}{lccc}
\multicolumn{1}{c}{ Показатель } & \multicolumn{3}{c}{ Группа } \\
\cline { 2 - 4 } & $\mathbf{1}$ & $\mathbf{2}$ & $\mathbf{3}$ \\
\hline $\begin{array}{l}\text { Средняя живая масса (г) в возрасте, } \\
\text { сут.: }\end{array}$ & $170 \pm 2,0$ a & $173 \pm 1,7$ a & $175 \pm 1,8$ a \\
\hline 14 & $460 \pm 5,6$ a & $475 \pm 6,1$ a & $483 \pm 5,06$ \\
\hline 21 & $863 \pm 5,5$ a & $893 \pm 6,6$ б & $892 \pm 6,46$ \\
\hline 28 & $1328 \pm 7,1$ a & $1344 \pm 10,0$ б & $1398 \pm 9,0$ в \\
\hline 35 & $1949 \pm 11,8$ a & $1958 \pm 11,0$ a & $1968 \pm 11,0$ a \\
\hline 39 & $2305 \pm 11,7$ a & $2398 \pm 10,3$ б & $2413 \pm 9,56$ \\
\hline Среднесуточный прирост живой массы, г & 58,1 & 60,5 & 60,8 \\
\hline Однородность по живой массе, \% & 83,0 & 82,8 & 81,3 \\
\hline Изменчивость живой массы (Сv), \% & 5,07 & 4,29 & 3,92 \\
\hline Сохранность, \% & 94,0 & 93,0 & 94,0 \\
\hline Расход корма на 1 кг прироста, кг & 1,87 & 1,72 & 1,62 \\
\hline Индекс эффективности выращивания & 297 & 332 & 359 \\
бройлеров, ед. & & & \\
\hline
\end{tabular}

Примечание: цифры в строках, помеченные разными буквами, различаются достоверно $(p<0,05)$. 


\begin{tabular}{|c|c|c|c|}
\hline \multirow{2}{*}{ Показатель } & \multicolumn{3}{|c|}{ Группа } \\
\hline & 1 & 2 & 3 \\
\hline Конечное поголовье, гол. & 940 & 930 & 940 \\
\hline $\begin{array}{l}\text { Выручка от реализации мяса } \\
\text { в убойной массе, тыс. руб. }\end{array}$ & 123,3 & 126,9 & 129,1 \\
\hline Полная себестоимость мяса, тыс. руб. & 118,4 & 113,4 & 109,1 \\
\hline Прибыль, тыс. руб. & 4,9 & 13,5 & 20,0 \\
\hline Уровень рентабельности, \% & 4,1 & 11,9 & 18,3 \\
\hline
\end{tabular}

8-14 суток 5\% при рекомендованном уровне питательности комбикорма 300,4 ккал ОЭ и 22,3\% СП; в период 15-21 суток 15\% при уровне питательности комбикорма 309, 1 ккал ОЭ и 21 ,5\% СП; в период 22-28 суток 20\% при уровне питательности комбикорма 312,9 ккал ОЭ и 20,9\% СП и в период 2935 суток 30\% при уровне питательности комбикорма 312,5 ккал ОЭ и $20,6 \%$ СП.

\section{Литература}

1. Влияние цельной пшеницы в рационе на живую массу и качество тушки цыплят-бройлеров / [s.a.] // Агропресс. - 2016. - № 5. - С. 16-18.

2. Корма и биологически активные кормовые добавки для животных / Н.В. Мухина, А.В. Смирнова, 3.Н. Черкай, И.В. Талалаева; под общей ред. Н.В. Мухиной. - М.: КолосС, 2008. $271 \mathrm{c}$.

3. Корма, кормовые добавки, биологически активные вещества для сельскохозяйственной птицы / Ю.А. Пономаренко, В.И. Фисинин, И.А. Егоров,
В.С. Пономаренко; под ред. Ю.А. Пономаренко. - М.: Россельхозакадемия, 2009. -656 c.

4. Кормление сельскохозяйственной птицы / В.И. Фисинин, И.А. Егоров, Т.М. Околелова, Ш.А. Имангулов. Сергиев Посад: ВНИТИП, 2000. - 376 с. 5. Ленкова, Т. Н. Эффрективность использования нетрадиционных видов зерна в комбикормах для бройлеров и кур-несушек // Птицефабрика. 2006. - №8. - С. 30-35.

6. Малородов В.В. Аэростазные зоны в помещении для выращивания бройлеров в холодный период года // Птица и птицепродукты. - 2019. - № 3. C. 46-49.

7. Османян А. Микроклиматическая зональность в помещениях для выращивания бройлеров в теплый и холодный периоды года / А. Османян, И. Салеева, В. Малородов, Р. Гайфуллин // Главный зоотехник. - 2019. № 7. - С. 52-59.

8. Османян А.К. Эффективность применения циркуляционных вентиляторов в помещении для выращивания бройлеров в холодный пери- од года / А.К. Османян, И.П. Салеева, А.Н. Третьяков [и др.] // Зоотехния. 2020. - №1. - С. 19-21.

9. Османян, А.К., Включение цельного зерна пшеницы в полнорационные комбикорма для бройлеров / А.К. Османян, В.3. Хамитова // Мат. XIX Междунар. конф. Рос. отд. ВНАП «Мировые и российские тренды развития птицеводства: реалии и вызовы будущего». Сергиев Посад, 2018. - С. 297-298.

10. Салеева И.П. Аэростазные зоны в производственных помещениях при выращивании бройлеров / И.П. Салеева, А.К. Османян, В.В. Малородов // Птица и птицепродукты. - 2018. № 3. - С. 34-37.

11. Салеева И.П. Выявление микроклиматических зон в птицеводческом помещении при выращивании бройлеров в теплый период года / И.П. Салеева, А.К. Османян, В.В. Малородов // Птицеводство. - 2019. №4. - С. 41-47.

12. Тишенкова Т.А. Цельное зерно пшеницы в рационах молодняка мясных кур: автореф. дис. ... канд. биол. наук. - Сергиев Посад, 2002. - 24 с.

Для контакта с авторами:

Хамитова Валерия
Зайдулловна
Тел.: +7 (8552) 74-60-40
Османян Артем Карлович
Тел.: +7 (499) 976-14-56
Малородов Виктор
Викторович

Тел.: 8-906-838-00-57

\title{
The Productive Performance in Broilers Fed Diets with Partial Substitution of Whole Wheat Grain for the Compound Feeds
}

\author{
Khamitova V.Z.', Osmanyan A.K.' ${ }^{2}$, Malorodov V.V. ${ }^{2}$ \\ 'Chelny-Broiler, Ltd., ${ }^{2}$ Russian State Agrarian University of K.A. Timiryazev
}

\begin{abstract}
Summary: The productive performance in broilers fed diets with partial substitution of whole wheat grain for the compound feeds was assessed on 3 treatments of Cobb-500 broilers (1-39 days of age, 100 birds per treatment) fed no grain (control), 5-20\% of the grain (treatment 2), and 5-30\% of the grain (treatment 3). The best results were obtained with the following scheme of the substitution: 5\% at 8-14 days of age, 15\% at 15-21 days, 20\% at 22-28 days and 30\% at 29-35 days (treatment 3). Prior to the slaughter (no less than 4 days) the grain should be excluded from the diets. This scheme increased live bodyweight at 39 days of age by $4.7 \%$ in compare to control $(p<0.05)$, average daily weight gains by $4.6 \%$, improved feed conversion ratio by $15.4 \%$, European production efficiency factor (EPEF) by $20.9 \%$, and profitability of broiler production by $14.2 \%$ in compare to control.
\end{abstract}

Keywords: broilers, full-diet compound feeds, whole wheat grain, productive performance, profitability. 